This survey, however, was not primarily concerned with language: it was equally concerned with the selection of papers for publication and with financial aspects, on which later, however, the only firm conclusion drawn was that no law of political economy appears to have any validity in this field of publication. Only in Canada did some effort appear to have been made to organize scientific publication financially and there is a very wide variation in the price demanded of the scientific subseriber for 10,000 words of scientific literature. Sometimes a single periodical has widely different subscription rates for different categories of subscribers; even within one country and one scientific discipline, rates may vary widely with no apparent explanation. The mean value for commercial publishing seems to be higher everywhere than the mean value for periodicals owned by non-profit concerns or societies, though a few exceptions can be found.

Submission of papers to a referee was practised by 71 per cent of the periodicals, but was not universal, especially outside the United States; 72 per cent of the periodicals publish author's' abstracts, but only 40 per cent decline to publish a paper unaccompanied by an abstract written by its author. Only 38 per cent of the periodicals appeared to be aware of the Guide for the Preparation of Synopses, in spite of the efforts made since 1949 by Unesco and the Abstracting Board of the International Council of Scientific Unions to distribute this and make it known; only a minority (6 per cent) of editors have taken steps to make it known to the authors of papers, while only a very few have framed and distributed their own rules.

The Aslib report is based on three studies carried out by Miss Moira Phillips, of the Aslib Research Department, but the introduction, while rightly stressing that in the immediate future an increasing proportion of the world's scientific literature will be in Russian, Chinese and Japanese, in urging the importance of a knowledge of these languages, and of cover-to-cover translations, appears to underestimate both the outstanding importance of English itself as a medium of communication and of the economic and other considerations which will tend to encourage publication in one or other of these four major media as against nationalistic considerations. The first of the three studies sought to establish how many hours of tuition were necessary to enable a scientist to acquire sufficient knowledge of Russian grammar, construction and vocabulary to understand Russian papers at least on his own subject. The second was a study of cover-to-cover translations with the view of seeing to what extent it would be feasible to meet the demand for translations by cover-to-cover publications. In this, Dr. D. J. Urquhart comments that the number of ad hoc translations made before a cover-to-cover translation is no measure of the use of the cover-to-cover translation, which is a disseminating medium in its own right. The third study was of the participation and co-operation in the Commonwealth Index of Unpublished Scientific and Technical Translations.

Summarizing the three studies, Mr. C. W. Hanson concludes that language barriers separate Englishspeaking scientists and engineers from about onethird of the world's scientific and technical literature, to which learning to read foreign languages, and especially Russian, at present offers the most direct approach. A reading knowledge of Russian sufficient to enable a scientist to make sense of a paper on his own subject can be acquired with about 50-200 hours of tuition, and it would be feasible to provide sufficient courses in the United Kingdom for about one-quarter of the annual output of graduate scientists and engineers. While the demand for cover-to-cover translations of individual articles is concentrated on a fow periodicals, the production of some additional cover-to-cover versions would be justified as providing ready-made translations of individual articles which may be needed. Generally, the demand for translations of individual articles is too thinly scattered over a large number of periodicals to justify a massive programme solely as a means of meeting demand. The need for translations to meet individual wants will continue, and co-operative indexes and pools provide a means of avoiding duplication of effort. The Commonwealth Index of Unpublished Scientific and Technical Translations operates at a profit to the community even when judged on the criterion of avoidance of duplication alone and has scope for growth. A study of the literature supports the view that the progress already made and the magnitude of the rewards of success justify major efforts in machine translation, although comprehensive machine-translation services comparable in adequacy and cost with those provided by human translators are unlikely to be achieved in less than a decado.

\title{
DANGERS OF DRINKING SEA WATER
}

$\mathrm{T}$ HE salt content of body fluids is about 1 per cent. In the open ocean the salt content of the sea is about 3.5 per cent. In health, when food and water consumption is adequate, the salt concentration in the body is kept relatively constant by the kidneys; it varies, but only within a small range. In a healthy individual suffering from deprivation of water the concentration of salt in the urine does not average more than 2 per cent. This difference in salt content between the body fluids and sea water, and the physiological inability of the kidney to excrete more than a certain proportion of salt in the urine, form the basis of the generally accepted view that drinking sea water does harm. It introduces a hypertonic solution into the circulation, water is withdrawn from the tissues to restore the osmotic balance between the tissues and vascular system, the blood volume is increased, and the kidney is called on to excrete the excess fluid. The net result is progressive dehydration of the tissues, leading to disturbances in the acid-base balance, a rise in the non-protein nitrogen of the blood and the plasma protein concentration, a reduced cardiac output, thirst, and, in due course exhaustion, collapse and death.

This view was challenged by Dr. Alain Bombard who crossed the Atlantic Ocean in 1952 on an inflatable raft, taking more than two months for the voyage and relying chiefly on sea water and fluids expressed from fish to quench his thirst. The opinion he reached after these trials on himself was that people 
should begin drinking sea water as soon as possible before dehydration starts but in small quantities only to avoid nausea and diarrhoea. Whatever fresh water is available should be carefully husbandod, and, if there is none, fluids should be expressed from fish by squeezing them in plastic bags or towels.

Bombard's experiments were followed by Dr. $G$. Aury, principal medical officer of the French Navy, who, in 1953 and 1954, carried out experiments on volunteers subjected to shipwreck conditions, he himself taking part. Aury described the experiments as boing successful; the sea water was readily drunk by the volunteers, they suffered from no werious complaints, and, when the experiments wero over, they were able to resume their duties immediately. Tho experiments lasted only 2-4 days.

A German physician, Dr. Lindomann, Inado no less than three voyages across the Atlantic ocean, in a canoe and thon in a collapsible boat. He reached diametrically opposite conclusions to those of Bombard and Aury. Sea water, he held, should nover be drunk; fluids could only be expressed from fish by means of a press; and no fish should bo eaten if no fresh water is available.

In 1959 the question of drinking sea water came before the Maritime Safety Committee of the InterGovernmental Maritime Consultativo Organization. The exporiments of Bombard and Aury, and the wide publicity they had received, created much confusion about the drinking of sea water, and the impression had spread that the dangers of drinking sea water had boen grossly oxaggerated. The Maritime Safoty Committee felt that an authoritative opinion was required on what had bocome a controversial quostion and asked the World Health Organization for its viows. Pending a firm opinion to the contrary, however, the Committes urged that no Governmonts should advocate the drinking of soa water by ship. wrecked mariners.

The World Health Organization convened a meeting of five internationally recognized experts, Surgeon Captain F. W. Baskervillo (United Kingdom), Dr. J. Fabre (Switzerland), Dr. H. Laborit (Franco), Prof. R. A. MeCanco (United Kingdom) and Prof A. V. Wolf (United States). They considered the offects of drinking sea water under three headings: effects on the bowel, on the body as a whole and on the mind*. Because of the well-known cathartic effects of salts, drinking sea water is likely to lead to intestinal discomfort, if not to frank diarrhœa. 'This effect varios in different individuals and is more likely to follow if large amounts are ingosted. On tho body as a whole, the offect of sea water is to overload the circulation with salt, which can only bo oxcreted by drawing on the body water and so dehydrating the body even more. If the salts are not excreted the cffect will be equally harmful because of the increaso in the concentration of salts in the body fluids. Finally, the evidence shows that even small amounts of sea water affect some individuals unfavourably, while large amounts havo been shown to lead to mental disturbances and even suicidal impulses.

Tho experts examined the contention that a limited supply of fresh water could be made to last longer if it were mixed with sea water. This has been shown to bo feasible exporimentally in certain animals and is theoretically possiblo in man. But the group emphasized - no acceptable evidence has ever bcen adduced that in man sea water can be used satisfactorily to eke out supplies of fresh water. This as yot unproved hypothesis cannot, therefore, bo made the basis of a practical recommendation for saving the livos of people shipwrecked at sea.

One of the ronsons for advocating the drinking of sea water is to preserve morale, which, in the circumstances of shipwreck, is likely to be low. The experts held the viow that morale can be maintained if it is made clear to the castaways that death from lack of water alone is searcely possible for several days. It has been shown from experimental work that a man can remain reasonably fit without wator for six days, and mon have survived without it for twice that period at soa. It has also been shown that $500 \mathrm{ml}$. (one pint) of fresh water daily, if possible supplementod by $100 \mathrm{~g}\left(3 \frac{1}{2} \mathrm{oz}\right.$.) of carbohydrate, will maintain a man almost without deterioration for at least six days.

The group ended its report with advice to thoso who have to abandon ship, including the warnings to "Never drink sea water. Never mix sea water with fresh water if fresh water is in short supply. Sea, water has been used to moisten the mouth, but the temptation to swallow it may be irresistible and it is better not to use it for this purpose. Never drink urine".

*WHO Chronicle, 16, No. 9 (September 1062).

\section{ECONOMIC LIFE OF CHEMICAL PROCESS PLANTS}

"E CONOMIC Lifo of Process Plant" was the subject of a symposium held under the auspices of the Institution of Chemical Engineers in London on October 30. Obsolescence of chemical process equipment is a vital factor which has to be taken into account by the enginen responsiblo for dosigning ehomical plants to operate at minimum cost over a reasonably predictable time, having regard to certain constraints governed by oporating conditions. The author of a paper on this subject, C. S. H. Munro, concludes ". . . that the physical durability is by no means the only determining factor in tho life of chemical plant equipment and that the dcsigner must consider vory carefully the future capacity requirements and the likelihood of proccss change". All requirements for capacity incroase of plant appoar to ariso after periods of more than fivo years ". . . which is perhaps as long as any commercial ostimates might be considered valid". The argument would seem to indicate a case for increasing depreciationratos to accord with actual chemical plant life, which, as is well known in the industry, is one of the most. difficult to assess compared with many othor engineering projects.

A mothod of determining economic optimum timing for replacing chomical plant was discussed by $H$. $R$. Fisher in his apparently new solution to this problem formulatod in Terborgh's Dynamic Equipment Policy (MeGraw-Hill Book Co.. New York, 1949). H. C. D. Phillips, D. A. Petors and J. A. 